\title{
The Haunting Temporalities of Transplantation
}

202I, Vol. 27(2) 58-82

(C) The Author(s) 2021

(c) (1)

Article reuse guidelines: sagepub.com/journals-permissions DOI: 10.1 | $77 /|357034 \times 2| 998729$ journals.sagepub.com/home/bod

@SAGE

\section{Donna McCormack (1)}

University of Surrey

\begin{abstract}
This article examines the temporality of organ transplantation with a focus on memoirs where the recipient has received an organ from a deceased donor. I argue that death constitutes life. That is, this absent presence - that the organ is materially present but the person is dead and therefore absent - is the foundation for rethinking relationality as constituted through the haunting presence of those who remain central to the continuity of life but who are not alive in any strict definition of the term. This article is therefore attentive to the various meanings of haunting, drawing on queer theory to show how narratives of haunting are derealised experiences and thus a struggle for epistemological authority over specifically transplantation and relationality more broadly. It draws out how these epistemological challenges reimagine ontology as a haunted experience, and thus an intimate tie between the living and the unknown - and somewhat present - dead.
\end{abstract}

\section{Keywords}

death, epistemology, haunting, memoirs, ontology, organ transplantation, queer temporality, time

\section{Absent Presences: Haunting Epistemologies and Ontologies}

In her memoir $A$ Change of Heart (1997), heart recipient Claire Sylvia explains the realisation that her donor was alive and present. The donor was not alive in any sense of how we may define human personhood, but rather in a newly experienced sensation of life beating strongly in Sylvia's previously weak and dying body. She portrays this sense of vitality not only as shared and embodied, but also 
as timely: 'I felt his future that was never to be' (1997: 160). Her words capture how the death of one person is that which enables her own continuity forward in time. Sylvia can feel what he cannot have: the future; she knows that receiving an organ is about gaining access to more time. I begin with this personal narrative of temporality in transplantation to capture how this article explores the repeated trope of haunting across transplant memoirs. I read hauntings in transplant memoirs as momentary glimpses of unbounded selfhood and nonlinear temporalities in otherwise normative life writing forms. I extend how we may understand the phenomenological, intertwined experiences of time and self through the lens of queer temporalities and the concept of haunting. Moreover, I build on phenomenological discussions (Gunnarson, 2016; Shildrick, 2012; Zeiler, 2014) that engage with alterity, inter-/intra-subjectivity and the 'singularplural nature of personhood' (Blackman, 2010: 5) by turning to the dead. That is, I examine how the dead may live on as vital organs within another being, and therefore how materiality, rather than presence of a whole person, constitutes life of both self and other. Indeed, this vital presence - but dead other - puts into question the possibility of distinguishing between self and other, individual and plural, presence and absence, and life and death.

My focus is deceased organ donation in memoirs because these texts engage with the language and experience of haunting. They are published on or after the advent of Cyclosporine, the first immunosuppressant that allowed transplantation to be viewed as a life-saving procedure (Starzl, 1992), and they originate from France and the United States. ${ }^{1}$ By analysing how memoirs engage with haunting, I am not suggesting that all recipients experience such phenomena. Rather, these memoirs frame organ donation as haunted. Haunting is the turn to a register of the unreal (Gordon, 2008 [1997]) and in so being brings into stark focus how the dead may feel alive and how the absent may feel present. It is this boundary slippage - where death does not mean absence - that, I argue, expands how we think the temporality of transplantation and, more broadly, of the self.

As part of this argument, I shift discussions of theories of self and other away from the dominant framework of a relationality between living beings (Hegel, 1977; Lacan, 1977 [1966]; Luciana, 2007; Oliver, 2001) towards a notion of vitality, where death may constitute life. The self emerges through a vitality of death, where the donor 
is dead and absent but their body parts alive and present. It is because of this ambiguity surrounding life and death that I turn to the various meanings of haunting, drawing on queer theory to explore how narratives of haunting are de-realised experiences and thus a struggle for epistemological authority over specifically transplantation and relationality more broadly. In so doing, I argue that these epistemological challenges reconfigure ontology as a haunted experience and thus an intimate tie between the living and the - somewhat present - dead. Importantly, I suggest that the temporal nature of selfhood more generally is always already haunted (even while it may not always be manifest in everyday life).

This analysis is based on five memoirs: Mary Gohlke's I'll Take Tomorrow: The Story of a Courageous Woman Who Dared to Subject Herself to a Medical Experiment - The First Successful Heart-Lung Transplant (1985); Claire Sylvia's A Change of Heart: The Extraordinary Story of a Man's Heart in a Woman's Body (1997); Noëlle Châtelet's book, with the recipient Isabelle Dinoire, Le baiser d'Isabelle: L'aventure de la première greffe du visage [Isabelle's Kiss: The Adventure of the First Face Transplant] (2007); Susan Whitman Helfgot's The Match: Complete Strangers, A Miracle Face Transplant, Two Lives Transformed (2010) and Mitchell Fink's text, with the recipient Robert Dunn, Change of Heart: A Black Man, a White Woman, a Heart Transplant and a True Love Story (2011). These memoirs emphasise heroic narratives of transplantation, which I would suggest is the dominant structure of many Anglophone and Francophone memoirs, but they also convey an emergence of alternative temporalities and selfhoods. In addition, while they defy genre classification, I analyse Jean-Luc Nancy's Corpus (2008), which includes his translated philosophical reflection on his heart transplant, and Francisco J. Varela's (2001) largely academic but also extremely intimate reflection on his liver transplant. While these two texts do not represent the vast majority of memoirs available in English or French, they capture the eruptions that emerge in the mainstream publications, which while normative in terms of life trajectory and bodily forms bear witness to the undoing of a linear self.

The article is structured through five sections: 'Illness Memoirs' explores how the selected texts set up an authority against whom the author-recipients struggle to forge an alternative epistemology of 
transplantation; 'Queer Temporalities' examines how queer in dialogue with multiple disciplines (including medical sociology, anthropology, phenomenology, feminist theory) is a methodological tool for thinking the temporalities of transplantation and selfhood, particularly in relation to non-normative embodiments and temporalities; 'Transplant Hauntings' analyses relationality as founded on haunting; 'Transplant Memoirs' explores mourning as a temporal return to an unknown past that may open up ways of dealing with one's sense of loss in transplantation; and the conclusion examines how transplantation opens us up to living with death's constitutive role in life. Thus, this article examines how death constitutes life and how the queer temporality of flesh reveals how absence may be presence, self may be both self and other, and death may be ongoing vitality.

\section{Illness Memoirs: Chrononormative Healthiness}

Narrative structures our understandings of health and illness, and the memoir in particular is "the story of having a "life" [that] coasts on a normative notion of biocontinuity' (Berlant and Prosser, 2011: 181). Speaking on illness narratives, Frank states: 'The conventional expectation of any narrative [...] is for a past that leads into a present that sets in place a foreseeable future' (1995: 55). Similarly, Gilmore emphasises the 'diachronic dimension' of illness narratives (2012: 94), where life moves from birth through illness to restored health, and, as Lochlann Jain argues, focuses on the 'ultimate "triumphs" of the treatments' (2013: 15). More specifically, transplantation narratives reiterate a heroic form where 'the practice and success of transplantation [...] supports and feeds the idea of limitless medical progress, ever-fixable bodies, and open-ended lifeextension [...]' (Kaufman, 2013: S58). This 'linear drive towards progress and outcome [constructs] transplantation as an "endgame," a culmination, a tale told' (Kierans, 2005: 345). Transplantation is imagined - and by this I mean constituted through a series of reiterative processes that normalise the technological intervention - as 'a series of interchangeable, equivalent presents - abstract organ-time' (Cooper, 2008: 127). The idea that 'the organ must be suspended in time' (Cooper, 2008: 110) reinforces that transplantation is a desire to bring about the self-same normative bodily form: a suspension of the whole, sealed body in the time it takes to restore it to its previous, 
supposedly healthy, form. The present is the time of an organ as a mechanistic part that replaces the same non-working part, and the future is the continuation of the somewhat altered body, but still restored to the same present where the body is oriented to a future of healthiness. I would suggest that the selected transplant memoirs conform to such normative temporal and heroic dimensions of illness narratives, often reinforcing the body as a singular entity momentarily disrupted by illness.

Despite this celebratory style and chrononormative form (Freeman, 2010), the memoirs, while sympathetic to transplant teams that support them and make their lives possible, are full of moments of disruption, non-linearity and hauntings. In the first heart and lung recipient's memoir, the surgeon states:

Sometimes when the families of donors learn the name of the recipient it causes psychological problems for them. They begin to believe their loved one isn't really dead, that he or she still lives inside the body of a total stranger. (Gohlke, 1985: 103, emphasis added)

While Gohlke emphasises that the surgeon dismisses such possibilities of donors living on as psychological issues, Sylvia criticises health professionals as 'usually quick to dismiss our reactions and feelings as illusory or unreal, although they themselves have never been in our situation. Moreover, most doctors and nurses don't even want to hear what we have to say' (1997: 199). Sylvia raises the important issue of experience, of sensing a changing body that may only be known by those who have undergone a transplant, suggesting an unwillingness of health professionals to listen.

Similarly, Dinoire, the first partial face transplant recipient, repeatedly states that her sense of self is distinct from how the transplant team wishes her to be: 'For the doctors, this face [of the donor] must be integrated, but the mouth is a part that will never be mine' (Châtelet, 2007: 249). ${ }^{2}$ Dinoire states that the donor is distinct from her even when doctors insist she must accept the donor as integral to her. Critical work on transplants reinforces this idea that such attachments are seen 'by professionals as pathological' (Davies, 2006: 260; Sharp, 2006). The selected memoirs highlight an epistemological struggle regarding the relationality between recipients and donors and/or donor families. They narrate a break in an authoritative 
narrative, in a cultural imaginary produced through their experience of medical practice and policy, recipient and donor and/or donor family narratives, popular culture, the media, scholarly work and centuries of western philosophy where the body is conceived as a whole and as restored to its whole self after surgical and technological intervention (Fox and Swazey, 1992; Shildrick, 2008).

To return such a sense of the human as whole and narrative form to chrononormativity would suggest, in line with Sharp, that: 'The biomedical model of time is wed to the rationale of disease theory; as such, a progression from diagnosis to treatment and cure is essential to the paradigm' (2006: 10). In this sense, '[health] itself [may] be seen as a side effect of successful normativity, [where] people's desires and fantasies are solicited to line up with that pleasant condition' (Berlant, 2007: 765). The temporality of transplant memoirs is forged through a desire to restore health and normality to a disrupted life and to structure life as forward-thrusting, restored and therefore continuous. However, in the above extracts, the authorrecipients position an authority against whom they must define their own experience of an uncertain self and in so doing these authorrecipients turn to a different order of time itself.

\section{Queer Temporalities: Promiscuous Methods}

Here, queer is a methodology, a way of reading the selected memoirs, and of analysing the concepts and lived experiences of time and embodiment. It is, as Freeman argues, a 'decision to unfold, slowly, a small number of imaginative texts rather than amass a weighty archive of or around texts, and to treat these texts and their formal work as theories of their own, interventions upon [...] critical theory' (2010: XVII). I therefore employ queer theory to read these memoirs as critical theory. Queer theory helps to understand the times and selves that emerge in moments of haunting.

More specifically, I revel in the promiscuous routes and histories of queer theory by dipping into and interlinking ideas across multiple disciplines without fidelity to any specific disciplinary tradition (Berlant, 1997; Cvetkovich, 2003; Halberstam, 2011). I follow Cooper's 'promiscuous' methods (2008: 4), which include the sociological, biomedical, anthropological, philosophical and in my case the literary, as well as Sara Ahmed's description of her 'preference for such queer 
turnings [which] is because I don't have a disciplinary line to follow I was "brought up" between disciplines and I have never quite felt comfortable in the homes they provide' (2006: 22). Disciplinary discomfort is a method for reading popular literary texts that explore experiences of biotechnological interventions through the register of haunting. I draw on two already interlinked strands of queer theory: (1) queer time (Dinshaw, 2012; Edelman, 2004; Freccero, 2007; Freeman, 2007; Halberstam, 2005; McCormack, 2015) and (2) queer as an undoing of embodied subjectivity (Butler, 2004a, 2004b; Chen, 2012; Haraway, 2016; Hird, 2009; Hird and Giffney, 2008). In so doing, I offer analytical tools for reading experiences that turn to the register of the unreal and therefore for a language that may account for such seemingly disruptive and potentially unscientific narratives.

While queer frames my methods, theories of illness temporalities are central to understanding haunting in transplant memoirs. Charon argues that for those who are unwell, their 'temporal states of being differ' (2006: 44) and that 'disease forecloses narrative coherence over time' (2006: 43-44). Frank emphasises illness as 'living with perpetual interruption' (1995: 56), precisely because 'its present is not what the past was supposed to lead up to, and the future is scarcely thinkable' (1995: 55). Furthermore, Charmaz links these temporal changes of illness to a transformed embodied self:

Living with serious illness and disability can catapult people into a separate reality - with its own rules, rhythm, and tempo. Time changes - drastically. [...] Having a chronic illness means [...] struggling to maintain control over the defining images of self and over one's life. (1997: 4-5)

While the restoration of a whole self may be central to these memoirs, I take the above reflections on illness temporalities as a queer potential to live with what Nancy calls 'a permanent regime of intrusion' (2008: 169). Rather than bodily integrity, I focus on 'the radically different senses of embodiment that transplants induce' (Blackman, 2010: 5) even when normative bodily and written forms are reproduced. The trope of haunting draws out the very constitutive - and rather queer - bond between life and death that founds selfhood. I agree with Varela that 'it is not the body-technology that introduces the alterity in my lived body', but rather the 'technology 
widens and slips into what is always already there' (2001: 266). In other words, a haunted sense of being with others that is prominent in transplant narratives, while clearly a trope of the transplant experience, is itself indicative of how the self gives 'way to a decentring into a larger field of subjectivity' (2001: 268). While transplant memoirs bring hauntings of the self into focus, I argue that the self is always already haunted, founded upon haunting absent and yet present dead but vital others.

My use of queer therefore builds on a phenomenological tradition of analysing morphologically diverse bodies, including the temporalities of biotechnologised bodies (Gunnarson, 2016; Haddow, 2005; Kaufman, 2010; Shaw, 2010; Zeiler, 2014). In particular, I work with Zeiler's 'temporal thickness' (2018: 88) and Merleau-Ponty's enfolding of body and time: 'I am not in space and time, nor do I conceive space and time; I belong to them, my body combines with them and includes them' (1962: 161). In so doing, this 'critical model of queer temporality [...] theorizes temporalities we already inhabit' (Gilmore, 2012: 94) and how we are always already founded by death, not as a future occurrence but as the very possibility of being. To this extent, Freeman's analysis of how 'time binds' means not simply temporal obligation, but, echoing Merleau-Ponty, 'that naked flesh is bound into socially meaningful embodiment through temporal regulation' (1962: 3). Thus, the emphasis on queer temporalities is to render apparent how a sense of self emerges through changing flesh, literally in the form of an organ, and that the potential change of time (practically in the regime of pharmaceutics and medical appointments and physically in feeling a past that is not one's own) may bind how selfhood emerges. Such structures of flesh and time impact how narrative is written, how chrononormativity becomes necessary to transplant memoirs, and therefore queer becomes a way to analyse moments when these bodies and times no longer stay together.

Building on Muñoz's argument that queer addresses 'failures of imagination' (2009: 18), I am suggesting that the register of the unreal - ghosts, hauntings and/or absent presences - has a place in this highly technologised and scientific field. Taking queer detours through multiple disciplines captures non-linear temporalities as the phenomenological experience of transplantation, for some recipients, and the queer undoing of normative bodily and temporal forms. If we 
live with our ghosts, as Muñoz suggests (2009: 46), then maybe we will tease out what haunting means to transplantation and as a mode of witnessing our unruly, inter-/intra-connected bodies and times. I employ a queer reading precisely because these heteronormative and chrononormative texts that are often read as too personal to be scientific offer a potential to think embodied temporality as both living with more than one in the so-called individual and vitality in death.

\section{Transplant Hauntings: Time and Flesh}

Sylvia speaks about her donor as 'this other presence within' (1997: 128), as feeling her 'ghostlike' post-transplant body (1997: 121), and concludes that 'the boundaries between life and death, or between this life and other possible lives, might not be as permanent or immutable as we generally assume' (1997: 120). Similarly, Dinoire says: "“The other," she will always be present' (Châtelet, 2007: 233). While this relationality with one's body and donor may be read as an interruption to the normative human who is conceived as whole, independent and alive (or dead, but never both), Sylvia's and Dinoire's words capture a haunting unspeakability of the relationship between the living and the dead. Their words reveal a temporal shift in and of the post-transplant body, where that which should be absent, namely the dead, is present. As the heart recipient Dunn states: 'I held my hand to my heart, and through my tears I told these people [the donor family] that I could even feel [the donor] Dorothy loving me, right at that moment' (Fink, 2011: 98). These recipients return to the almost tangible but not present, and in so doing bear witness to what has been lost: namely the one to whom one feels indebted and whose presence is visceral but whose absence is supposed to be as definitive as death. Here, time is queer in its refusal to move forward as the recipient constantly returns to the unknown past of the donor; cohere with the normative demands of the distinction between the living and the dead; and reinforce the human as one, individual being and instead showing intimate relationality.

Furthermore, where Hoeyer (2010) reveals that bone is understood as waste and thus a useful resource for others and not necessarily a property of self, I would argue that these transplant memoirs show relationality as not only emerging through the donated organ, but more specifically the organ itself as vitality, as the very thing that 
gives life. In Dinoire's words, 'That which gives life, is it not life?' (Châtelet, 2007: 17). Dunn says, 'I knew I felt love for this anonymous person whose heart had given me life' (Fink, 2011: 97). The organ itself stands in for the very possibility of the present: life is only possible because there is vitality in this organ and thus death and life are bound together. It becomes impossible to separate the life of self from the sense of renewed health that comes from the donated organ and thus the dead donor. Such phenomena could be said to capture a sense of 'bodily immortality' (Haddow, 2005: 109), and what Shildrick calls 'an atemporal bioethics' (2019: 20). However, I want to stress that this is not only about socio-medico-cultural understandings and redefinitions of death. I am arguing that it is precisely at the point where it becomes almost impossible to distinguish between life and death that flesh in these memoirs is felt as that which prolongs life and therefore as the very thing that gives life. Although the person has died there is vitality, and perhaps more importantly, to return us to Freeman's work, this captures how flesh binds us. In other words, rather than atemporality or immortality, I would suggest that the fleshed self is 'constitutively haunted' (Derrida, 2005: 179-180). While bone as waste may not found connections, body parts as vitality are experienced as the very possibility of continuity, literally of temporality itself. Thus, Derrida's (1994) ghosts return us to the other within as simultaneously alive and dead, present and absent, and self and other, and the very possibility of these distinctions. Vitality exceeds the individual who has died and thus the sense of better health and/or changed embodiment (including scars, side effects of medications, etc.) come to be felt as the site of life itself. Time loops back to the donor who is no longer alive and yet whose time has not ceased in the organ that may be felt as change to the recipient's self and present. Here, the ghost - or the figure of haunting - is not a pathological failure to accept death or anxiety (Kierans, 2005; Shildrick, 2015), but a capturing of the queer temporalities of transplantation and relationality more broadly.

Furthermore, the temporality of flesh crosses and may extend, or indeed be shorter than, the life of a supposedly singular being. Whitman Helfgot's The Match is a memoir where the recipient subsequently donates the received heart, showing that vitality extends beyond two lives. It becomes critical to grapple with the implications of such temporalities when one experiences life extension through 
the vital death of an other. Dinoire states this the most explicitly when she tries to convince the psychiatrist that she should know the donor's history: 'How do you want me to mourn that which I've lost if I don't know how that came about?' (Châtelet, 2007: 242). It should be clear that I am not calling for a policy change where recipients should know about the donor. My point is that no amount of knowledge could fill this sense of loss of self and loss of other, as haunting is constitutive of being. Instead, transplantation exposes how absent presences constitute our very sense of who we are as always multiple beings and temporalities, whether this be in the form of a deceased donor or an ecology of living bacteria in and on the body (Martin, 2010).

It is not only recipients who feel this bind. Donor families are presented in memoirs, and often in popular sources (Fuller, 2018), as sensing the presence of their dead family member living on. They read the material form (i.e. the donated organ) as presence. Sylvia describes meeting the parents of her donor, Tim, and these are the words of Tim's father: 'It made me feel my son came back to me [...]. His spirit is still there in those parts she received' (1997: 197). The son is present, but not alive in any strict sense; he is there through his heart that continues to beat in Sylvia. Donors are a haunting reminder of the continuation of life after death, but perhaps more importantly they show how humanness is constituted through the time of body parts: that life can go on even in partialised form and thus that the time of the organ donor does not stop with death. This re-turn to the dead person, who is seen to be re-formed in and re-forming of the other, is evidence of a haunting materiality. The time of the donor is a re-turn not as self but as life to an other, as a material entity that may alter the other's sense of self and the distinction between life and death.

The temporality of transplantation, in the form of haunting, brings to the fore the very queer materiality of the life of the other as it constitutes the self. The material presence of the dead donor - the suggestion that the donor lives on through the donated organ - constitutes a haunting temporality where the self may live with a dead other or more accurately accept that a dead other constitutes one's self. Here, the temporality of selfhood is not only about life's forward drive but also about remembering what is lost and living with the proximity of death itself. The trope of haunting bears witness to 
being more than one, even when the self may be understood as a singular, embodied being. In these memoirs, the donor is dead, but the material presence of the donor's organ is also the fact of life itself, and thus the possibility of time continuing in its queerer - looped to the past - forms. If flesh emerges through and in time (MerleauPonty, 1962; Zeiler, 2018), then a change in flesh may produce a different temporality of being (with others). Hauntings question forward-thrusting, heroic narrative forms and the body as (restored to) a whole self. If death is not simply absence, then it may be that what these memoirs narrate could help in opening up transplant narratives to how we live with the dead, how some recipients may feel their bodies as more than one and how time may not only move forward.

\section{Transplant Memoirs: Haunting as Embodied Mourning}

Thus far I have suggested that death as absence fails to account for how flesh may feel similar to or even the same as presence (Bird Rose, 2017; Haraway, 2016), and that theories of self and other relationality which rely on presence ignore the very absences that constitute our sense of being with others. Here, I turn to mourning as a way to develop how we read hauntings and to suggest opening up transplant narratives to these queerer bodily and temporal forms. While existing practices designed to remember the deceased donors (e.g. annual ceremonies) may help some recipients mourn the donor they never knew, I would suggest mourning (as a theory and a practice) - with its emphasis on the repeated return to the past as a way into the future - could open up understandings of how life and death, self and other, presence and absence, multiple times and selves are constitutively bound. In other words, a queer reading of these memoirs does not refract disruptions or disturbances through a psychological lens, but rather gives space to living with the dead as simultaneously integral to and separate from the living and as presence and absence. Thus, '[d]eath may not, after all, be the end of life [because] after death comes the strange life of ghosts', which is when 'multiple unruly temporalities' may become evident (Tsing, 2017: G8). The structure of mourning - as a queer method of living with the dead - gives us glimpses of narrative eruptions where we witness what could be described as impossible experiences, such as the dead 
living on, and thus a way of practicing living with absent dead, but vitally and materially present, others.

Author-recipients often speak of themselves - and are often described - as 'reborn' (Châtelet, 2007: 18, 28, 121, 292; Sylvia, 1997: 95) post-transplantation. The period pre-transplantation is for some a sense of losing life and time itself. Sylvia explains: 'As I grew weaker, my sense of time started to change. On the one hand, I probably didn't have all that much of it left. On the other hand, time was just about all that I did have' (1997: 50-51). Time is fading as the fear of the last breath structures daily life. Gohlke describes knowing she was 'running out of time' (1995: 77), and Dinoire relates this sense of time ending to the loss of self: 'I had lost the sense of time, without question, of things, of reality. I didn't know who I was anymore' (Châtelet, 2007: 37). Furthermore, descriptions of donors reinforce the experience of transplantation as a temporal confusion. Whitman Helfgot, speaking about her husband who received a donated heart and went on to donate that heart and his own face, explains how technology keeps donors 'suspended as if in a cocoon, ghostlike, hovering between this world and the next' (2010: 39). Gohlke says: 'the brain-dead body [of] the donor [...] was kept alive until the time of surgery' (1995: 115). Prior to the organ procurement ghosts are present, and the borders between the dead and the living are blurred as the time of death is both at the moment of brain death and when the technology is turned off. Ghosts may not be possible, but they clearly haunt many aspects of organ transplantation, and precisely because 'in certain cases our death can prolong another person's life' (Whitman Helfgot, 2010: 261). Such blurrings reveal ontological and epistemological questions around how we live with death, not simply as an end but as integral foundational - to our being and how immaterial materiality (hauntings as immaterial and the organ as matter that links back to ghostly tropes) founds relationality. Ghostly language takes us into an uncertain boundary between life and death and where one life and person end and another begins.

Mourning is a way of reading through the normative structures of health memoirs (and narrative more broadly) to explore the meanings of ghosts in this biotechnological field. Importantly, it could help to understand ways of living with these ontological and epistemological uncertainties, rather than always reducing such reactions or emotions 
to psychological or psychiatric readings. Following Butler, I argue that loss of an other is a loss of who one is, or more specifically death exposes the tie that is foundational to one's very being. In Butler's words, this relationality 'is to be conceived as the tie by which those terms ['you' and 'I'] are differentiated and related' (2004a: 22). This is why the death of an other may 'haunt the way I am' (Butler, 2004a: 28), and thereby result in one being 'undone and open to becoming unbounded' (Butler, 2004a: 28). While I agree with Butler that death exposes the very relationality of being with others, I want to stress that in transplantation, a recipient may be understood not only as psychically 'unbounded' but also as physically 'unbounded', in the sense that the body's boundary is cut open and body parts removed and reinserted. This literal undoing, I would argue, adds to the sense of feeling 'undone' by the loss of an unknown other whose vitality and thus relationality is the foundation of self. Importantly, the self is not founded through a living tie, but through loss itself, and the very physical undoing in the form of surgery brings mourning into play as a process of trying to understand changing bodily existence and how time continues post-transplantation. Mourning is the experience of a queer temporality that reaches back to an unknown other whose vitality is present but who is clearly absent insofar as they are dead, and thereby a sense of loss comes with visceral and relational changes.

The heart recipient Robert Dunn explains: 'I had told [the donor's] family once that I could feel [the donor] Dorothy loving me. But now I could feel myself loving her. It was as if I was falling in love with her, and the feeling was as overwhelming as it was comforting' (Fink, 2011: 102). Such a sense of co-existence is captured by Gordon when she describes 'how that which appears absent can indeed be a seething presence' (2008 [1997]: 17). I am suggesting that the taking of an organ from a dead other founds a relationality and a relational temporality that could be said to run counter to the human, to its very linear-oriented and life-oriented goals. And, such counternarratives emerge in the memoir form, where the need for a narrative of healing, of overcoming illness to triumph into wellness, is present but is constantly disrupted by a time that does not only move forward and by narrators who want the dead to be present. Sylvia says: 'I felt as if I were two people who were sharing the same body' (1997: 158). Similarly, Dinoire states, 'Forget her, no./ I can't and I won't. She 
exists in me. She will always be in me and she will always be a part of me' (Châtelet, 2007: 247). No one other than the recipient can feel these changes, this presence and these bodily differences. This produces a sense of haunting precisely because the materiality that is of the other - but is not the living other - evokes an epistemological and ontological uncertainty about the simultaneity of life and death, presence and absence, and of this time and of belonging to a past (indeed, finished) time. Following Derrida (2005), I suggest that in transplantation, self and other relationality is constituted at the limits of knowledge, at the limits of present, knowable others. It may be reassuring to hear that the donor cannot live on, and this may be scientifically accurate, but the repeated testament to ongoing life through the sense of an other in the post-transplant self should at least raise some epistemological and ontological uncertainties about this biotechnological intervention. It may not be that the donor is living on, as such, but that a sense of altered and shared being is possible and that this is not simply anxiety-inducing but rather a way of being that gives recognition to the relationality between the dead and the living.

Moreover, visceral touching is central to this sense of material presence and thus to the idea of the dead living on, of haunting in transplantation. The queer sense of haunting in transplant memoirs returns us to phenomenology and how critics have explored bodily registers other than sight as foundational to relational being (Jay, 1994; McCormack, 2014; Oliver, 2001). I want to queer this reliance on living touch to suggest that transplantation exposes how we are touched over and over again by that which is beyond the living: sometimes dead and oftentimes full of vitality. In transplant memoirs, this uncertain touch originating from a dead person, but not the dead person, whose time is over, but whose organs live on, impacts how recipients relate to their bodies and their sense of futurity. Varela addresses this quandary by referencing accounts of a dozen people online: 'we feel our livers, doctors say we shouldn't. [...] Such is the presence of the unfeeling liver' (2001: 264). Similar to memoirists, Varela evokes the prohibition of particular knowledge about transplantation and insists that insides may be felt. Nancy, Gohlke and Dunn all use the word intruder to describe how they sense their failing organs and the donated parts, and Sylvia uses a potentially less aggressive expression: 'this other presence within' (1997: 128). 
Interiority is felt as intrusion, as the failing organ, regardless of whether scientifically it is possible to feel one's liver or other organs. Unlike in Hoeyer's exploration of bone transplantation where questions of self and other relationality were largely absent for donors and recipients, memoirs raise questions around how we sense the inside of ourselves and thus how this presence - intrusion - brings to the fore a viscerality that may otherwise have been considered absent. In so being, the transplanting of vitality through deceased organ donation continues to be felt over time. This transports touch in the phenomenological tradition into another dimension as the living touch the dead inside themselves.

Building on Husserl's discussion of how touch may precede presence, Derrida states that 'the ghostly revenant [ ... ], between life and death, dictates an impossible mourning, an endless mourning - life itself' (2005: 35). Following Derrida and Butler, I am arguing that mourning founds a relational tie that is the very possibility of being, and thus mourning in the case of transplantation is one way to grasp the varying levels of loss: of being more than one, of feeling an attachment to the dead or even that the dead live on and of being irrevocably transformed by the fact of inter-/intra-subjective existence. The intrusion to which Nancy refers in the title of his philosophical memoir (2008) and thus the sense of interiority that is brought to the fore pre-transplantation persists as one's own sense of life wanes and is prolonged through the insertion of one (or multiple) organ(s). Interiority and exteriority become almost indistinguishable and therefore what supposedly divides self from other almost impossible to discern. While the resealing of the body's border might be understood as reasserting the division between inside and outside, self and other, it raises more issues around how the self was never simply individual and how death does not mean the cessation of vitality even if an other is dead. Furthermore, I would suggest that the literal touch of an other through the vital organ reinforces the sense that one may feel what one is not supposed to feel (if we return to Varela). One is literally touched by the warmth of the dead, not in the form of an individual being but rather through their constitutive part(s). In organ transplantation, embodied time is 'a passage outside and through the other, as well as through absence, death, and mourning' (Derrida 2005: 180). Indeed, Sylvia explains how she is 'joined' to her donor Tim: 'Tim was now part of me, and I was part of him' 
(1997: 114). She describes post-death and post-transplant relationality as: 'I had finally achieved my new identity, a kind of third being that was neither the old Claire nor the new Tim, but some combination of the two' (1997: 209). Dunn speaks of a similar tie to his donor, stating: "He [God] must have said [to the donor]: "Come with me. You'll be safe, and you'll live in somebody else. And I have the perfect somebody picked out for you." That's really how I feel' (Fink, 2011: 101). In these memoirs, the experience of being literally open to an other (and sometimes multiple others) and thereby that the embodied self passes through a temporality of mourning is a return to an unknown past through the sense of an other in the self who is dead and yet whose vitality is central to life. This is an insistence that the dead donor lives on in the body of the transplantee; it is a turn to ghostly possibilities as an epistemological and ontological challenge to conventional understandings of organ transplantation as outlined in the memoirs.

Furthermore, the memoir form gives the above claims potential credibility. The genre's personal narrative gives it a veracity that is in many ways its 'ethical appeal' (Gilmore, 2012: 91). The aim of transplant memoirs could be said to be 'to enhance the humanity of those who write and read it, to amplify the domain of human control, and to promote a view of the autobiographer as one who can shape life through its representation' (Gilmore, 2012: 91). In addition, it shows the appeal of this biotechnology, revealing its miraculous, life-saving qualities, and how the struggles, while immense, are always outweighed by the fact of life going on. Although the overarching narrative is one of success, even when the recipient's death is narrated (Fink, 2011), these ghosts - these hauntings - disrupt the flow of a life from health to illness to near-death and back to life again. Similar to Gilmore's argument in relation to pain memoirs, I would suggest that transplant memoirs do not offer a linear, progressive narrative of the individual human. Precisely because the reconstitution of the self is not the recreation - the replication - of the self in the same body but instead the creation of a new bodily form that is similar to and yet different from who one was prior to transplantation, the form of the writing is not strictly realist or linear. Hauntings are possibilities for speaking of our constitutive ties to the dead, as well as bearing witness to a temporality that repeatedly returns to the losses of those we do not know but who found our fleshy existence. 
Memoirs, read for their queer potentialities, open mourning up to a complex queer temporal disruption that founds relationality through death and through absent presences. Mourning is never over, if we follow Derrida and Butler, and therefore life post-transplantation is a living with the past as constant presence and death as integral to being. Haunting is not exceptional but rather more apparent in transplantation; it is foundational to being.

\section{Conclusion: Death as Life's Constitutive Companion}

On 26 October 2018, the British newspaper The Guardian published an interview with the British football player Andy Cole. Having recently undergone a live kidney transplant, Cole talks about how he is 'struggling emotionally [and] physically' (McRae, 2018). He insists that, despite his ongoing depression and suicidal ideation, transplantation is a 'fantastic thing [because] you can live another day' (McRae, 2018). Yet Cole also speaks openly about his fears: 'But you never know how long your kidney will last. It could be here for five or ten years. It could fail tomorrow' (McRae, 2018). Similarly, Gohlke describes 'death as a constant companion' (1985: 13). She continues: 'For the first time since my transplant, I really thought about death. I had come to grips with death when I was ill, but now I had been given a reprieve and I had to come to terms with it again' (1985: 165). Sylvia echoes these fears:

One reason I had been ambivalent about this operation was that assuming it worked, it would mean dying twice. After a transplant you're thrown back into life with the knowledge that some day you'll have to go through the whole process of dying all over again. (1997: 95, emphasis added)

What each of these recipients - whether from living or deceased donations - speaks of is their intimate knowledge of and their proximity to death. While it is obvious that all humans will die, the temporal structure of healthiness allows for a denial of this process. If recipients are distressed post-transplantation, then this intimacy with death, I would argue, is an important factor to be considered. Transplantation is largely founded on death, often the death of the other, as I have explored here, but also the death of self over and over again (Lock, 2002). To walk with death is possible and does not have 
to be distressing, but if we deny our very relationality to mortality as heroic narratives of transplantation often do, claiming to conquer death and illness - then this makes living intimately with death very difficult. Memoirs show that post-transplant life is structured through the temporality of return, and the future is this attachment to the past. In so doing, these author-recipients disrupt heroic transplant narratives as the only possible epistemology and the individual body as the only possible ontology.

This proximity to death is central to existence and is obvious in transplantation, and yet is potentially different from those who work with death on a day-to-day basis. Transplant recipients, in the selected memoirs, feel death's proximity as vitality in the self, as well as the loss of parts of self and the unknown other. This is critical as it captures that these transplant recipients live with death as a potential end, as an ongoing sense of vitality and as a companion, which makes the experience of life and selfhood feel much more intimately tied and open to others. It is not that transplantation is unique, but rather it reveals how we are already open to each other, already undone by the interior beings on whom we depend and that we walk with death. Mourning is a way to open up transplantation to not only heroic, miracle narratives and to annual ceremonies where the dead are remembered, but also to a sense of coming undone, to the possibility of living with more than one being in the self (or more specifically with one's self as multiply formed) and to one's repeated uncertainty in having to face death daily. Queer temporalities capture this possibility of mourning as the borders between inside and outside, absence and presence and death and life are undone for the transplant recipient. Queer, here, is reading texts by recipients as challenges to epistemological authorities, as pieces of gratitude to health professionals, donors and donor families, and as testimony to alternative experiences and supposedly impossible ontologies.

Hauntings are most apparent in narratives of deceased organ donation, where the visceral flesh of the dead donor opens up the possibility of an intimate relationship with the recipient. The self comes to be founded on a relationship with a being that one never knew and will never know and thus on a search for who one might be now that one's body lives with the flesh of a dead other in the self. I have explored how this is not about distress or anxiety, but rather that it shows how the temporality of life is not linear and is constituted 
through an intimate relation with absent - and yet materially present others. The dead may be absent insofar as death is understood as the end of life, but transplant memoirs show that the dead may feel physically present even if not alive in any strict sense of the term. Moreover, the intimate relation with death, knowing that this organ is what has extended time and thereby life itself, creates a difficult context for moving forward easily, not only because of the need to realise who one is post-transplantation and the loss of an unknown other but also because of the knowledge that one has to go through the process of dying again. Transplantation is not simply about the future, about a brighter, healthier life, it is also about living with death, loss and grief. Thus, to only look forward, to imagine life as future-oriented, does not give space to how life is intimately tied to those absent presences. Death and absence - and their very distinctions from and ties to life or vitality and presence - are integral to how we exist with others both already inside the self, welcomed into the self and felt as outside. Hauntings are narrative explorations of queer moments where normative bodily and temporal forms are undone. Mourning is the temporal loop that bears witness to the past in the present, the future as a return to the past, the dead as vital and the absent as present.

\section{ORCID iD}

Donna McCormack 으 https://orcid.org/0000-0002-2852-2180

\section{Notes}

1. My aim is not to analyse why certain people publish memoirs. My starting point, similar to that across literary and social science studies, is that narrative should be analysed for what it offers to our thinking on specific socio-political and cultural phenomena. Indeed, I take popular culture as a particularly rich area of learning how narratives gain currency and circulate, influencing popular and more specialised perceptions of, in this case, organ transplantation. My focus is deceased organ donation because this brings to the fore the potential for a relationality between the living and the dead and because memoirs that deal with deceased organ donation also repeatedly turn to such prohibited forms of relationality. However, my overall point is that selfhood is constituted by absent others, who may be materially present in an unrecognised form. 
2. The emphasis in the original text indicates that these are Dinoire's own words. The memoir is written in two clear voices: the author's and the recipient's in italics. One could argue that is simply how memoirs work, in that there is most often a professional writer. However, in the case of transplantation, it raises the issue of how to write in one's own voice when it speaks as more than one. I do not explore this issue here. Also, in the original, it is clear that the donor is a woman, but this is lost in the translation. This text has not been published in English and therefore all translations are my own and page numbers refer to the French text.

\section{References}

Ahmed, Sara (2006) Queer Phenomenology: Orientations, Objects, Others. Durham, NC: Duke University Press.

Berlant, Lauren (1997) The Queen of America Goes to Washington: Essays on Sex and Citizenship. Durham, NC: Duke University Press.

Berlant, Lauren (2007) Slow death (sovereignty, obesity, lateral agency). Critical Inquiry 33(4): 754-780.

Berlant, Lauren and Prosser, Jay (2011) Life writing and intimate publics: a conversation with Lauren Berlant. Biography 34(1): 180-187.

Bird Rose, Deborah (2017) Shimmer when all you love is being trashed. In: Tsing, Anna et al. (eds) Arts of Living on a Damaged Planet. Minneapolis, MN: University of Minnesota Press.

Blackman, Lisa (2010) Bodily integrity. Body \& Society 16(3): 1-9. Butler, Judith (2004a) Precarious Life: The Powers of Mourning and Violence. London: Verso.

Butler, Judith (2004b) Undoing Gender. New York, NY: Routledge. Charmaz, Kathy (1997) Good Days, Bad Days: The Self in Chronic Illness and Time. New Brunswick, NJ: Rutgers University Press. Charon, Rita (2006) Narrative Medicine: Honoring the Stories of Illness. Oxford: Oxford University Press.

Châtelet, Noëlle (2007) Le Baiser d'Isabelle: L'aventure de la Première Greffe du visage [Isabelle's Kiss: The Adventure of the First Face Transplant]. Paris: Seuil.

Chen, Mel Y (2012) Animacies: Biopolitics, Racial Mattering and Queer Affect. Durham, NC: Duke University Press. 
Cooper, Melinda (2008) Life as Surplus: Biotechnology and Capitalism in the Neoliberal Era. Seattle, WA: University of Washington Press.

Cvetkovich, Ann (2003) An Archive of Feeling: Trauma, Sexuality, and Lesbian Public Cultures. Durham, NC: Duke University Press.

Davies, Gail (2006) Patterning the geographies of organ transplantation: corporeality, generosity and justice. Transactions of the Institute of British Geographers 31: 257-271.

Derrida, Jacques (1994) Specters of Marx: The State of the Debt, the Work of Mourning and the New International, Kamuf, Peggy (Trans.). New York, NY: Routledge.

Derrida, Jacques (2005) On Touching - Jean-Luc Nancy, Irizarry, Christine (Trans.). Stanford, CA: Stanford University Press.

Dinshaw, Carolyn (2012) How Soon Is Now? Medieval Texts, Amateur Readers and the Queerness of Time. Durham, NC: Duke University Press.

Edelman, Lee (2004) No Future: Queer Theory and the Death Drive. Durham, NC: Duke University Press.

Fink, Mitchell (2011) Change of Heart: A Black Man, A White Woman, A Heart Transplant and A True Love Story. Bloomington, IN: Open Books Press.

Fox, Renée C and Swazey, Judith P (1992) Spare Parts: Organ Replacement in American Society. Oxford: Oxford University Press.

Frank, Arthur W (1995) The Wounded Storyteller. Chicago, IL: Chicago University Press.

Freccero, Carla (2007) Queer times. South Atlantic Quarterly 106(3): 485-494.

Freeman, Elizabeth (2007) Theorizing queer temporalities: a roundtable discussion. GLQ: A Journal of Lesbian and Gay Studies 13(2-3): 177-195.

Freeman, Elizabeth (2010) Time Binds: Queer Temporalities, Queer Histories. Durham, NC: Duke University Press.

Fuller, Mike (2018) The poignant moment when a little boy met the family of the girl who gave him a heart. Chronicle Live. Available at: https://www.chroniclelive.co.uk/news/north-east-news/poignantmoment-little-boy-met-14610034 (accessed 28 September 2019). 
Gilmore, Leigh (2012) Agency without mastery: chronic pain and posthuman life writing. Biography 35(1): 83-98.

Gohlke, Mary, with Max Jennings (1985) I'll Take Tomorrow: The Story of a Courageous Woman Who Dared to Subject Herself to a Medical Experiment - the First Successful Heart-Lung Transplant. New York, NY: M. Evans and Company.

Gordon, Avery (2008 [1997]) Ghostly Matters: Haunting and the Sociological Imaginations. Minneapolis, MN: University of Minnesota Press.

Gunnarson, Martin (2016) Please Be Patient: A Cultural Phenomenological Study of Haemodialysis and Kidney Transplantation Care. Lund: Lund Studies in Arts and Cultural Sciences.

Haddow, Gill (2005) The phenomenology of death, embodiment and organ transplantation. Sociology of Health \& Illness 27(1): 92-113. Halberstam, Jack (2005) In a Queer Time and Place: Transgender Bodies, Subcultural Lives. New York, NY: New York University Press.

Halberstam, Jack (2011) The Queer Art of Failure. Durham, NC: Duke University Press.

Haraway, Donna (2016) Staying with the Trouble: Making Kin in the Chthulucene. Durham, NC: Duke University Press.

Hegel, GWF (1977) Phenomenology of Spirit, Miller, AV (Trans.). Oxford: Clarendon Press.

Hird, Myra (2009) The Origins of Sociable Life: Evolution After Science Studies. Basingstoke: Palgrave.

Hird, Myra and Giffney, Noreen (eds) (2008) Queering the Nonhuman. Aldershot: Ashgate.

Hoeyer, Klaus (2010) After novelty: the mundane practices of ensuring a safe and stable supply of bone. Science as Culture 19(2): 123-150. Jay, Martin (1994) Downcast Eyes: The Denigration of Vision in Twentieth-century French Thought. Berkeley, CA: University of California Press.

Kaufman, Sharon R (2010) Time, clinic technologies, and the making of reflexive longevity: the cultural work of time left in an ageing society. Sociology of Health \& Illness 32(2): 225-237.

Kaufman, Sharon R (2013) Fairness and the tyranny of potential in kidney transplantation. Current Anthropology 54(S7): S56-S66.

Kierans, Ciara (2005) Narrating kidney disease: the significance of sensation and time in the employment of patient experience. $\mathrm{Cul}$ ture, Medicine and Psychiatry 29: 341-359. 
Lacan, Jacques (1977 [1966]) Ecrits: A Selection, Sheridan, Alan (Trans.). London: Routledge.

Lochlann Jain, S (2013) Malignant: How Cancer Becomes Us. Berkeley, CA: University of California Press.

Lock, Margaret (2002) Twice Dead: Organ Transplants and the Reinvention of Death. Berkeley, CA: University of California Press.

Luciano, Dana (2007) Arranging Grief: Sacred Time and the Body in Nineteenth-Century America. New York, NY: New York University Press.

Martin, Aryn (2010) Microchimerism in the Mother(land): blurring the borders of body and nation. Body \& Society 16(3): 23-50.

McCormack, Donna (2014) Queer Postcolonial Narratives and the Ethics of Witnessing. London: Bloomsbury Academic Press.

McCormack, Donna (2015) Transplant temporalities and deadly reproductive futurity in Alejandro González Iñárritu's. 21 Grams European Journal of Cultural Studies 19(1): 1-18.

McRae, Donald (2018) Interview with Andy Cole: 'I apologise now to everybody for being the way I've been'. The Guardian. Available at: https://www.theguardian.com/football/2018/oct/26/andycole-manchester-united-interview-kidney-transplant?

$\mathrm{CMP}=$ Share_iOSApp_Other (accessed 26 October 2018).

Merleau-Ponty, Maurice (1962) Phenomenology of Perception, Colin, Smith (Trans.). London: Routledge.

Muñoz, José Esteban (2009) Cruising Utopia: The Then and There of Queer Futurity. New York, NY: New York University Press.

Nancy, Jean-Luc (2008) Corpus, Rand, Richard A (Trans.). New York, NY: Fordham University Press.

Oliver, Kelly (2001) Witnessing: Beyond Recognition. Minneapolis, MN: University of Minnesota Press.

Sharp, Lesley (2006) Strange Harvest: Organ Transplants, Denatured Bodies and the Transformed Self. Berkeley, CA: University of California Press.

Shaw, Rhonda (2010) Organ donation in Aotearoa/New Zealand: cultural phenomenology and moral humility. Body \& Society 16(3): 127-147.

Shildrick, Margrit (2008) Corporeal cuts: surgery and the psychosocial. Body \& Society 14(1): 31-46. 
Shildrick, Margrit (2012) Imagining the heart: incorporations, intrusions and identity. Somatechnics 2(2): 233-249.

Shildrick, Margrit (2015) Staying alive: affect, identity and anxiety in organ transplantation. Body \& Society 21(3): 20-41.

Shildrick, Margrit (2019) (Micro)chimerism, immunity and temporality: rethinking the ecology of life and death. Australian Feminist Studies 34(99): 10-24.

Starzl, Thomas (1992) The Puzzle People: Memoirs of a Transplant Surgeon. Pittsburgh, PA: University of Pittsburgh Press.

Sylvia, Claire, with William Novak (1997) A Change of Heart: The Extraordinary Story of a Man's Heart in a Woman's Body. London: Little, Brown \& Company.

Varela, Francisco J (2001) Intimate distances: fragments for a phenomenology of organ transplantation. Journal of Consciousness Studies 8(5-7): 259-271.

Whitman Helfgot, Susan, with William Novak (2010) The Match: Complete Strangers, A Miracle Face Transplant, Two Lives Transformed. New York, NY: Simon \& Schuster.

Zeiler, Kristin (2014) A phenomenological approach to the ethics of transplantation medicine: sociality and sharing when living-with and dying-with others. Theoretical Medicine and Bioethics 35: 369-388.

Zeiler, Kristin (2018) On the Autós of autonomous decision making: intercorporeality, temporality, and enacted normativities in transplantation medicine. In: Aho, Kevin (ed) Existential Medicine: Essays on Health and Illness. London: Rowman and Littlefield, pp. 81-100.

Donna McCormack is a senior lecturer in English Literature at the University of Surrey. She is currently working on an AHRC Leadership Fellowship on Transplant Imaginaries. Her main research interests are biotechnologies in contemporary literature and film, evolutionary theory, postcolonial studies and queer theory. Her first monograph is entitled Queer Postcolonial Narratives and the Ethics of Witnessing (Bloomsbury Press, 2014), and she has published in the European Journal of Cultural Studies, Somatechnics and BMJ Medical Humanities, as well as in edited collections such as Bodily Exchanges, Bioethics and Border Crossing (Routledge, 2015). She is the coordinator of the Nordic Network for Gender, Body, Health, as well as a founding member of the Monster Network. 